
\title{
EXPLAINING WOMEN'S POSITION
IN THE WORKFORCE: A SOCIAL
POLICY ANALYSIS
}

\author{
Celia Briar \\ Massey University
}

\begin{abstract}
This paper begins by briefly examining the major patterns of gender inequality in paid and unpaid work in New Zealand and similar nations. It then looks at a series of possible explanations for these patterns. The main focus of the paper, however, is on the role of the state, and it questions whether, in the light of the theoretical discusssion, the state should be regarded primarily as an institution which has perpetuated an unequal division of labour along gender lines, or whether the state (actually or potentially) can improve the position of working women. The paper ends by asking what the most effective strategies might be to reduce gender inequality at work.
\end{abstract}

Despite research demonstrating strong and consistent patterns of gender inequality in paid and unpaid work there is still a tendency for mainstream writers in social policy and some official publications to overlook or neglect to explain these findings. The first interim report of the Prime Ministerial Task Force on Employment (1994) provides the most recent example of such neglect.

This paper therefore begins with a descriptive analysis of the patterns of inequality in women's participation in paid and unpaid work in New Zealand, before examining theoretical explanations of the role of the state. Finally, a possible agenda for change is outlined.

The aim of this paper is to link a feminist theoretical analysis of the role of state employment policy to an exploration of some ideas for a new agenda for change. If it remains true to say that the primary purpose of feminist theory is that it should lead to action, the question is what kind of policy change is required, and how can it best be brought about?

\section{Conceptualising the problem}

Unequal gender divisions have long been a major feature of the organisation of paid and unpaid work. During the present century the inequalities which have been most consistent have been: lower levels of participation by women in paid work and different patterns of participation, including marginality, different life cycle pattems of participation, high levels of hidden unemployment and underemployment, horizontal and vertical labour force segregation and lower pay.

Despite the frequently-cited rises in women's labour force participation rates, especially that of married women, since World War II, the level of women's participation in paid work, even at its height, in 1987, never approached that of men; involving only 54.5 per cent of women (full and part time combined) compared with 78.9 per cent of men (NACEW, 1990). Furthermore, international evidence shows that those rates have now levelled off in most age groups and in most countries; and there has actually been a fall in the employment of women aged over 55 in recent years (Bakker, 1988). In New Zealand women's overall labour force participation rates showed a decline for women working over 20 hours per week between 1986 and 1991 (Statistics New Zealand, 1993:81-2; NACEW,1990).

Whilst women's labour force participation rates are still appreciably higher than before World War II, women still do not participate on the same terms as men. Women have long been regarded as a flexible reserve labour force by policy makers. Pearce (1987) maintains that despite women's increased labour market participation rates about half of (American) women workers are still on the margins of the labour market in the sense that they are part time, seasonal, casual or homeworkers (outworkers) who are unlikely to earn a living wage and have no fringe benefits or prospects for improvement.

Women's patterns of participation in paid work also differ from men's during the life cycle. In recent years the pattern of women's involvement in paid work in countries which do not have a systematic policy of providing child care for the children of working parents has been the distinctive 'twin peaks'one: the 'dip' in the middle occurs as women take on child care responsibilities, but the second 'peak also declines in women's 50s as 'community care' policies 
have provided older women with additional caring responsibilities.

The extent of unemployment amongst women has been underestimated in New Zealand (Shipley 1982). In most OECD countries, the statistics indicate clearly that women suffer higher levels of unemployment than men, but in Britain and New Zealand, the most commonly used statistics disguise this.

Another difference in women's patterns of labour force participation is the growing extent of underemployment amongst women. Bakker (1988) demonstrates that there has been a fall in the average number of hours worked by women. This can be attributed largely to the growth of part time employment in virtually all of the western nations of the world.

Much of the literature which is available on women and work has as its focus the problem of horizontal and vertical occupational segregation: the 'crowding' of women into a narrow band of occupations, and the concentration of men at the top of occupational hierarchies. Research shows that although the actual jobs seen as 'women's work' tend to vary between nations, the patterns of occupational segregation by gender remain the same (OECD 1985). Both OECD and NACEW show that there is little decrease in occupational segregation because young women are still tending to enter 'traditional' female occupations.

Women's average incomes are considerably lower than men's. At the time of the 1991 New Zealand census $40 \%$ of women had annual personal gross incomes of under $\$ 10,000$ and $76 \%$ had incomes below $\$ 20,000$; and women's median total annal income was only $59 \%$ of men's (Department of Statistics, 1993:108-9). The reality therefore is that women are still likely to be at least partially financially dependent upon men during what are considered to be the most productive years of their lives, despite the large increase in labour force participation rates by women with families. This reinforces women's responsibility for unpaid work. Women worldwide consistently perform more unpaid work than men, which in turn limits women's ability to sell their labour. Contrary to popular belief, the amount of unpaid household labour performed by women has not declined during the present century, and the proportion of household work performed by wives has actually increased. Women still perform at least $70 \%$ of unpaid household labour (Bittman 1991).

This is not to suggest that all women have identical patterns of employment or are equally disadvantaged. Horsfield and Evans (1988) and NACEW (1990) demonstrated the different patterns of paid employment amongst Maori and Pakeha women, and found that Maori women are employed in a different range of employment, are more poorly represented in senior positions in both the public and private secotors and are more likely to be unemployed. Women with disablilities also have particularly high levels of unemployment (Wicks, 1992), and lesbians have been victims of workplace discrimination (Raven 1992), which although now illegal is not the subject of positive action to redress this.

It is also true that not all men have the same opportunities in the paid workforce (Collinson and Hearn, 1994). However, inequalities between men and between women should not be allowed to obsure overall patterns of gender inequality at work.

\section{The state: trick or treat?}

Historically the state has played a major role in reinforcing women's unequal position in paid and unpaid work (Briar, 1987; Sharp and Broomhill 1988). Policies have taken a number of forms. They have included treating women as men's dependents, for example through the 'marriage bar' between the wars (Briar, 1987) and more recently the 'cohabitation rule' in the administration of state benefits (Saville Smith, 1987). During the present century the state has played a part in keeping women's wages low by agreeing to the 'family wage' for men and by paying lower wages to its own women employees until the 1960 s (Briar, $1987 ; 1992 \mathrm{a}$ ) as well as by its non interventionist approach to lower pay for women in the private sector until the mid 1970 s. The creation of part- time work by the British state from 1943 as a wartime expedient also helped to maintain women's position as men's partial dependents, despite the growth in demand for labour after the war, and also helped to maintain women's position as marginal members of the paid workforce (Briar 1992b).

The marginalisation of working women has also been reinforced through training policies and patterns of recruiment and demobilisation in wartime (Summerfield, 1984; Briar 1987). In New Zealand and Britain statefunded childcare geared to the needs of working mothers has been widely available only in situations of exceptional demand for labour (Easting, 1994).

However, even in New Zealand and Britain, where policies towards working women may be characterised as more oppressive than progressive, important improvements have been secured through state legislation. These have included carers' benefits such as the Domestic Purposes Benefit, equal pay legislation in the public and private sectors and equal opportunities regulations in the state sector. Limited though these are, when combined with longer term changes such as the vote, superannuation and married women's property rights, these have made an important difference to women's lives.

In countries where the state has 'intervened' to a greater extent to provide working women with greater assistance this has had a significant impact on levels and patterns of participation in paid work (Behrend, 1994; Calasanti and Bailey, 1991; Hyman 1994: 185). By contrast, when the state is 'rolled back' the tendency has been for more unpaid responsibilities fall upon women through 'community care', state employment (a major source of paid work for 
women) is cut back and deregulated labour markets provide women with even less protection. Income inequality tends to widen as the role of the market increases, leaving women, the largest low income group, relatively worse off.

\section{Theorising state policies towards working women}

It is important to have a theoretical understanding of the forces which create both the oppressive and the progressive policies at the level of the state. In this section two questions are addressed: firstly whose interests are served by women's subordination at work and secondly, who has the greatest power to promote their interests at the level of the state?

I will look at three perspectives on the question of who benefits from gender inequality at work.

\section{Gender inequality at work in everyone's interest or no one's interest}

Theorists operating from within market liberal perspective have tended to assume that men's and women's roles in paid and unpaid work are the result of individual choice. This allows liberals to ignore the advantages to men of women's disadvantaged position, and also thus implicitly assumes one of two things. One assumption is that most women are making irrational choices by taking time out from their careers in the paid work force in order to care for small children, aged or sick relatives and healthy husbands. This view is well critiqued by Bunkle and Lynch (1992). The alternative assumption is that prioritising their husbands' careers rather than their own is a rational choice that many women make (New Zealand Treasury, 1989). If inequality remains, it can then be safely assumed that women have chosen their situation.

By contrast a liberal feminist perspective assumes that no one benefits from women's disadvantaged position in paid and unpaid work. It is assumed, for example, that employers have no incentive to discriminate against women, because if they did so they would restrict the pool of talented workers available to them, and thus other, more enlightened and less sexist employers would then drive them out of business (New Zealand Employers' Federation, 1985). Although liberal feminists have actively pursued change via the state their analysis leads to a tendency to underestimate the size of barriers to equality at work (Sharp and Broomhill, 1988).

Finally a functionalist viewpoint assumes that gender stereotyping in paid and unpaid work is unimportant: that women and men's roles are equal-but-different and complementary. Although all of these views can easily be critiqued, they continue in various forms to underpin much mainstream writing which influences social policy. Many maintream writers in the field of economics, sociology and social policy have continued to treat gender divisions at work as theoretically insignificant (Walby, 1985; 1986).

\section{Gender inequality at work in the interests of capitalism}

Marxism is above all a theory of work under capitalism and has created some useful tools of analysis for explaining structural inequality at work. However, for the most part the emphasis has been on class inequality, and the patterns of gender inequality at work have not been adequately explained.

It has often been assumed that women are kept as men's semi dependents in the home and as low paid marginal workers in the labour force so that capitalism can more easily exploit them and create maximum profits (MacIntosh; Sharp and Broomhill, 1988). However, this does not in itself explain why it is normally women rather than men that are treated this way (Walby, 1985).

One might expect that since women are usually lower paid than men, that women would be used as substitutes for highly paid men on a more general basis. However low paid women have been used to deskill and take over men's skilled trades far less than might have been expected. Employers have often been apparently easily persuaded to retain higher paid male workers even when cheaper trained women are available (for example at the end of both World Wars).

Earlier Marxist and socialist feminist writings which assumed that the gender division of paid and unpaid work were in the interest of capitalism have tended to be modified because of the difficulty of proving that gender divisions and the split between public and private worlds are any more beneficial to capitalism than any other form of social organisation. Some socialist feminist writings, along with liberal feminists have therefore tended to assume, therefore, that gender divisions at work are simply the result of old fashioned ideas.

\section{Men benefit from gender inequality at work}

Writers from several different schools of thought have agreed that the persistence of gender inequality at work can be explained in terms of its benefits to men. The authors include some socialist, radical and materialist feminists, a few conservatives and some male writers in the field of critical gender studies. Not surprisingly given the diversity of contributors, there is no complete agreement about which men benefit the most (husbands, fellow workers or employers), or what is the nature of the benefit to men (economic power, status, sexual power or a more general form of control).

Some socialist feminists have argued that men as workers in male dominated trade unions have acted to exclude women from 'men's jobs' and from the better paid positions within occupations, thus strengthening their own economic position in the paid workforce at the expense of women (Hartmann, 1981; Walby, 1986; Cockburn, 1983; 
1991; Burton, 1986). Hartmann (1981) has argued that men colluded with employers at the level of the state by pushing for the 'family wage' which they knew would reduce women's pay and force women into economic dependency on men.

In addition some conservative women who would not normally be described as feminists, such as Ann Knowles of the New Zealand Employers' Federation, have recently argued that women will be better off following the Employment Contracts Act and the weakening of male-dominated trade unions.

Despite the apparent similarity of ideas there are some major areas of disagreement, however. Whereas socialist feminists would normally prefer to see greater involvement of women in less patriarchal trade unions to obtain better working conditions and pay for both women and men, some conservatives would rather see women being used to undercut men's pay in a largely non unionised workforce.

Materialist feminists have argued that men in general benefit from women's subordination. Some have focussed upon the material benefits to men of women's unpaid household labour (Delphy, 1984; Delphy and Leonard, 1992). Delphy (1984) has argued that women's unpaid activities in the home of producing washed and ironed clothes, meals, a comfortable clean home and childcare, as well as varying degrees of direct assistance with the man's paid work, allow men to more effectively compete in the paid workforce. This analysis of men's material interest provides a convincing explanation for the continuance of gender inequality in the distribution of household work.

Hartmann (1981) has argued, also from a materialist perspective, that the domination of women in the households and the paid workforce are mutually reinforcing. Women's low paid and insecure position in paid work pushes women into partial or full dependence on a male 'breadwinner', and of being obliged to take on the main burden of unpaid household work and caring. At the same time, family responsibilities place limits on the time and energy a woman can devote to developing her own career in paid work, especially as she has to compete with men, most of whom have wives to assist them. A number of male writers, in the area of critical gender studies, has also begun to examine the ways in which men as men benefit from gender inequality at work (Collinson and Hearn 1994).

All of these writers acknowledge the ways that men workers or employers or both - have been able to benefit from women's position as unpaid and low paid workers.It would probably be true to say, however, that in policy terms in New Zealand this is the set of ideas which has tended to be most neglected.

\section{Whose interests are reflected at the level of the state?}

Writers from the social administration tradition tended to regard the state as benevolent, reformist or neutral. Those from the critical social policy tradition since the 1970 s, and some socialist feminists have been likely to see the state as reflecting the interests of capitalism (despite having a degree of autonomy). Although many feminists see the state as reflecting the interests of men either more than or in addition to capital, because feminists have tended to under theorise the state (Sharp and Broomhill, 1988) there has been a relative shortage of material theorising the state's polices towards working women.

Feminists who have theorised the state's employment policies have tended to perceive the state as acting in the interests of both patriarchy and capitalism, whether as separate conflicting systems (Walby, 1986; 1990), as separate but colluding (Hartmann, 1981) as a single system of capitalist patriarchy (Eisenstein, 1986) or as patriarchal capitalism (Briar, 1987; Calasantiand Bailey, 1991). The main problem with the notion of a single system or one where capitalism and patriarchy are in harmony is that it gives a pessimistic impression of women's opportunities to make positive changes for working women via the state.

Some feminist writers have argued that despite the weighting of power towards patriarchal and capitalist interests, women are not powerless, and have succeeded in obtaining some concession in the past. They therefore argue that the state should still be seen as an arena for struggle (Sharp and Broomhill 1988).Walby's characterisation of patriarchy and capitalist interests as being in conflict is potentially useful. However in her analysis patriarchy is equated only with male workers, whilst employers are seen as purely capitalist. Taken to its logical conclusion this would regard working women's continued subordination as evidence that working men are in a stronger position than capitalists, which is not a sustainable position.

I am inclined to agree with Eisenstein (1984) that employers tend to be patriarchal as well as capitalist in their interests; and with Hartman's (1981) view that there has been collusion between working men and employers at the level of the state. However, I do not share Sharp and Broomhill's view that this then means that the state's policies are not accessible to change. Rather I would echo Hartmann's view that there was no foregone conclusion that employers and working men would regard themselves as having sufficient shared interests to combine to disadvantage women. Morover, I would argue that it is still possible, at a time when social inequality between owners of capital and working men is widening, that men might come to perceive their interests as lying in helping to develop a policy agenda which benefits both working women and men.

\section{Alternatives}

I have argued that the state can have an important role in reducing inequality in society, and that when this happens women, who form the largest low income group are usually the greatest beneficiaries in financial terms. I will argue that policies that have been predominantly aimed at women, such as equal pay and opportunities legislation and anti- discrimination laws, which have been only par- 
tially successful in meeting their stated objectives (Briar 1994) should be retained and improved. However, there are other policies which would have greater impact upon women's lives without necessarily being aimed only at women, and which could therefore command a higher level of support.

Two policy alternatives are briefly outlined below, which if implemented would have a huge impact on women's lives, but should also benefit and appeal to men. They have in fact been campaigned for by men more than by women so far.These are: a universal basic income and a shorter working week.

\section{A Universal Basic Income (UBI)}

We need to restate a basic fact which was widely understood and which underpinned social policy in New Zealand and other market economies for many decades until comparatively recently. That is that the economies which rely primarily on the market for the distribution of income will not ensure economic security for all citizens (Walter, 1989).

A Universal Basic Income (UBI) means a payment based on the cost of living to every man, woman and child. There have been a number of New Zealand proposals for a Universal Basic Income, including recent ones by Keith Rankin (1992) and Auckland Unemployed Workers Rights Centre (1994). These have involved a reorganisation and streamlining of the tax/benefit system: however, there are schemes which have been developed overseas which have focussed upon sources of revenue other than income tax.

Much of the discussion surrounding the notion of UBI has centred around how it would be financed; although numerous schemes have been developed and costed. Equally important, however, is the question of the principles which should underpin a scheme (Walter 1989). Arguably even if a scheme ends up costing no more that the present tax/ benefit system, it should be redistributive and should remove poverty traps. No low income earner should be worse off at present, and if possible those on middle income should be at least as well off if not better than at present.

In this paper I am primarily concerned with the likely effects of UBI on women, although it should be mentioned that a scheme would also meet the needs of male and female students of all ages, the unemployed (who would be less stigmatised as a result of receiving an income as of right), volunteer workers, retired people and those wishing to start their own businesses.

Unpaid work, which is still largely done by women, provides a massive (although at present uncounted) contribution to the economic and social base of New Zealand. UBI would provide an income for carers and would effectively be putting greater value on domestic and caring work than at present. It would also provide a form of paid maternity leave or parental leave.

It might be argued by opponents that a basic income paid as of right would undermine incentives to seek or remain in paid employment. In fact, because of the present 'poverty traps' caused by the abatement levels for unemployment benefits DPB and pension, UBI would increase the financial incentives for low income people to move into paid employment. This would be because UBI would continue to be paid when people became employed. High income earners often have the most prestigous and best paid jobs, and because of this would be unlikely to give up paid employment in order to live on their basic income, although sabbatical leave might start to extend to a wider range of occupations.

However, it has been suggested by one advocate of UBI that one group who might move out of the labour force in the short term at least might be partnered women with children who are currently employed in very unsatisfactory part-time jobs, since women would not have to be in paid employment in order to make a financial contribution to the household or to have economic independence. Walter (1989) argues that in the longer term employers would have to offer better terms and conditions of employment to attract this group of women back to work. He also claims that women's full time participation rates would increase, especially in the longer term.

\section{A shorter standard working week}

The world trend during the past century has been to gradually reduce hours of paid employment. For example in the United States in 1870 the normal working week was in the region of 75 hours per week, whereas by the beginning of World War II it had been reduced to 42 hours (European Policy Institute 1993).A shorter standard working week is being explored and to some extent already being implemented in continental Europe with the support of the unions and many employers.

However, in many many countries (particularly the English speaking ones such as New Zealand) during the past 10-15 years this trend has ben reversed and the notion of the standard 40 hour working week is becoming rapidly lost. In Australia it has been shown that despite the existence of an average standard working week of under 38 hours, the average number of hours actually worked by full time employees is closer to 44 hours per week, with a significant proportion regularly working in excess of 49 hours per week (Dawkins and Simpson; 1993; Wooden,1993). This upward trend was particularly strong during the 1980s (Wooden, 1993:315). Similar trends have been observed in Britain, suggesting that this is a trend throughout the English speaking world. It is particularly male workers that are working these long hours. This makes men unavailable to take an equal share of domestic and childcare responsibilities.

Potentially the time freed by the growth in the use of new 
technology can be used to create a better society, where people have more time to spend with their children, to maintain their homes and gardens, to pursue hobbies, to helping work in their local community or on the marae, to do voluntary environmental work and to maintain friendships. Instead of this, in New Zealand as in Britain and the United States, there are now many people forming a 'core' or 'primary' workforce, but often working excessive hours, to the detriment of their own physical and mental wellbeing and that of their families. Others, particularly women (but also growing numbers of men) are now engaged in 'flexible' part- time work which creates partial economic dependency, since it normally does not pay a living wage. These are the 'underemployed', and most of them are women.

It is first important to relaim the notion of a standard working week, even if it began at 40 hours and was then gradually reduced by an hour per week each year.After five years it would be feasible to consider the notion of the four day week, which has been on the agenda of many groups for a number of years. However, to be of maximum benefit to women with children, the aim should be to gradually reduce the length of the working day so that it is brought down in stages to the length of the school day. It is possible that childfree workers could have the option of a four day week instead, because there could be room for flexibility to meet the needs of employers and employees within the shorter hours. It also means that women can work hours which are seen as 'normal' not 'atypical' which makes discrimination against women workers more difficult.

\section{Conclusions}

It seems necessary to attempt changes through the state, for despite the state's poor track record in bringing about improvements for women, it has nevertheless provided a lead to private industry and often provided women with a more reliable income than the household has done.

We cannot assume that everyone wants change which liberates women. Nonetheless it is in many ways the interests of both women and men to form an alliance to create an agenda for change which benefits both. Men have divided the working class in the past by colluding with employers and excluding women from the better paid jobs. Women's response has been policy demands designed mainly to benefit women and children.

If these gains are made women ( and many men) will be materially better off. The degree of choice for women is then potentially greater. However reducing economic inequality is not totally empowering. In the USSR and East Germany until recently women had greater economic equality with men, yet there was a lack of women in decision making positions, and no strong women's movement. Within the family women still had major responsibility for unpaid work and were still vulnerable to domestic violence. We need to know more precisely in what ways women's lives are changed by economic independence. In the meantime we can assume that there will still require to be an autonomous women's movement, whether or not women obtain economic equality.

\section{Future Research}

More research is required to find the most effective means of achieving a universal basic income and a shorter working week. In addition we need to know more precisely what effects these policies are likely to have on women's patterns of employment and quality of life. This may necessitate historical and cross cultural research looking at the effects of economic independence for women where it has occurred. We also need to look at the circumstances under which men and women can cooperate to achieve policies of mutual benefit.

\section{References}

Auckland Unemployed Worker' Rights Centre 1994 Employment: issues and solutions: a perspective from the Aotearoa Network of Unemployed Beneficiaries July, Auckland Unemployed Workers' Rights Centre

Bakker, I. 1988 Women's Employment: a Comparative perspective In JJenson (ed)The Feminisation of the Labour Force, Oxford University Press, New York : $17-41$

Bittman, M. 1991 Juggling time: How Australian families use time, Office of the Status of Women, Department of the Prime Minister and Cabinet, Canberra

Behrend, H. 1992 Women Catapulted into a different social order: women in East Germany Women's History Review 1(1):141-154, 1992

Briar, C. 1987 Women and State Employment policy, 1905-1985 unpublished $P h D$ thesis, University of Sheffield

Briar, C. 1994 Tracing the Patterns: The Development of EEO in New Zealand and Overseas In J.Sayers and M.Tremaine (eds)The vision and the reality, Dunmore Press, Palmerston North : 25-44.

Briar, C. 1992a Women, Economic Dependence and Social Policy in C.Briar, R.Munford and M.Nash (eds)Superwoman where are you? Social policy and women's experience Palmerston North, Dunmore Press : 41-68.

Briar, C. 1992b Part Time Work and the State in Britain 1941-1947 In B.D.Warme, K.L.P.Lundy and L.A.Lundy (eds) Working part-time: risks and opportunities Preager, New York : 75-86.

Bunkle, P.and Lynch, J. 1992 What's Wrong with the New Right? In C.Briar, R.Munford and M.Nash (eds)Superwoman Where are You? Social policy and women's experience Palmerston North, Dunmore Press : 23-40. 
Burton, C. 1986 Equal Opportunites Programmes In Grieve, N. and Burns A. (eds) Australian women: newfeminist perspectives Oxford University Press, Melbourne : 292-304.

Calasanti T.M. and Bailey C.A. 1991 Gender Inequality and the Division of Household Labor in the United States and Sweden: a Socialist Feminist Approach in Social Problems 38 (1): $34-53$

Cockburn, C. 1991 In the way of women: men's resistance to sex equality in organisations, Macmilan, London

Collinson D. and Hearn J. 1994 Naming men as men: implications for work, organisation and management In Gender, work and organisation 1 (1): 2-22.

Delphy, C. 1984 Close to home : a materialist analysis of women's oppression, Hutchinson London

Delphy, C. and Leonard, D. 1992 Familiar exploitation, Polity Press, Cambridge

Easting S. 1994 Women, childcare and the state. Unpublished Masters Thesis, Massey University.Palmerston North

Eisenstein, Z.R. 1986 The radical future of liberal feminism Northeastern University Press, Boston

European Policy Institute 1993 The 4-day week: a new model of working time in Europe London, European Policy Institute

Hartmann, H. 1981 The family as the locus of gender, class and political struggl: the Example of housework Signs 6(3)

Horsfield, A. and Evans, M. 1988 Maori women in the economy Ministry of Women's Affairs/ Department of Statistics, Wellington

Hyman, P. 1994 Women and economics: a New Zealand feminist perspective Bridget Wiliams Books, Wellington

National Advisory Council on the Employment of Women 1990 Beyond the Barriers NACEW, Wellington

New Zealand Employers' Federation 1985 Positive action manual: implementing equal opportunities in the workplace NZEF Wellington

Organisation for Economic Cooperation and Development 1985 The integration of women into the economy OECD Paris

Pearce,D. 1987 On the edge: Women Marginal Workers and Employment Policy. In C.Bose and G.Spitze (eds) Ingredientsfor Women's Employment Policy,
State University of New York Press, Albany

Rankin, K. 1992 Escaping the poverty trap: a proposal for a Universal Basic Income' Political Review, April, 1 (2): $28-40$

Raven, A. 1992 Lesbians and Equal Employment Opportunity policy in the state sector. In Briar, C. Munford,R. and Nash M. (eds) Superwoman where are you? Social policy and women's experience Palmerston North, Dunmore Press

Sharp R. and Broomhill R.1988 Short changed: women and economic policy, Allen and Unwin, Wellington

Shipley, S. 1982 Women's employment and unemployment, Society for Research on Women/Massey University Department of Sociology, Palmerston North

Statistics New Zealand 1993 All About Women, Statistics New Zealand, Wellington

Summerfield, P. 1984 Women workers in the Second World War, Croom Helm, London

Walby S. 1985 Theories of Women, Work and Unemployment. In L.Murgatroyd (ed) Localities, class and gender, Pion Ltd., London.

Walby, S. 1986 Patriarchy at work, Polity Press Cambridge

Walby,S. 1990 Theorising patriarchy, Polity Press Cambridge

Walter, T. 1989 Basic income: freedom from poverty, freedom to work, Marion Boyars, London

Wicks, W. 1992 Women with Disabilities: Some Aspects of Invisible Lives. In Armstrong, N. Briar, C and Brooking, $\mathrm{K}$. (eds) Women and work: directions and strategies for the 1990s Massey University, Palmerston North

Wooden, M. 1993 Overemployment, Unemployment and the Work Sharing Debate Australian Bulletin of Labour, 19 (4):314-321

\section{Author}

Celia Briar is a Senior Lecturer in the Social Policy and Social Work Department of Massey University, Private Bag, Palmerston North. 